\title{
Kebijakan Formulasi Hukum Pidana Dalam Penanggulangan Tindak Pidana Terorisme Di Indonesia
}

\author{
Natalia Budi Darma ${ }^{*}$, Sri Endah Wahyuningsih ${ }^{* *}$ Latifah Hanim $^{* * *}$
}

* Mahasiswa Magister (S2) IImu Hukum UNISSULA Semarang, email: nb.darma@gmail.com

${ }^{* *}$ Dosen Fakutlas Hukum UNISSULA

${ }^{* * *}$ Dosen Fakutlas Hukum UNISSULA

\begin{abstract}
ABSTRAK
Penelitian ini dilatarbelakangi oleh adanya permasalahan yang ada dalam pelaksanaan sinergitas antara Polri, TNI dan masyarakat dalam rangka penanggulangan tindak pidana terorisme, dimana permasalahan tersebut menjadi problematika hukum saat diusulkan Rancangan Undang-Undang Terorisme. Permasalahan dalam penelitian ini adalah bagaimana problematika hukum dalam pelaksanaan sinergitas Polri, TNI dan Masyarakat dalam upaya penanggulangan tindak pidana terorisme, bagaimana kebijakan hukum pidana saat ini yang diterapkan dalam penanggulangan tindak pidana terorisme dan bagaimana kebijakan formulasi hukum pidana yang diterapkan dalam penanggulangan tindak pidana terorisme di masa yang akan datang.

Metode penelitian ini yuridis empiris dengan metode pengumpulan data studi kepustakaan, wawancara dan pengamatan. Kerangka konseptual dalam penelitian meliputi konsep kebijakan hukum pidana, dan konsep tindak pidana terorisme. Sedangkan permasalahan ini dianalisis dengan menggunakan teori kedaulatan negara dan teori sistem hukum.

Hasil penelitian ini menunjukkan bahwa problematika hukum dalam pelaksanaan sinergitas Polri, TNI, Pemerintah dan Masyarakat dalam upaya penanggulangan tindak pidana terorisme di Indonesia berasal dari: perbedaan visi misi antara Polri dan TNI dalam tujuan dilakukannya sinergitas untuk pemberantasan tindak pidana terorisme; perbedaan pandangan mengenai RUU Terorisme antara Polri dan TNI. Kebijakan hukum pidana yang diterapkan saat ini dalam rangka penanggulangan tindak pidana terorisme di Indonesia antara lain dilakukan dengan cara penerapan UU Tentang Tindak Pidana Terorisme, UU Pemberantasan dan Pencegahan Tindak Pidana Pendanaan Terorisme dan UU Darurat tentang Senjata Api. Kebijakan formulasi hukum pidana di masa yang akan datang antara lain membuat perubahan dalam RUU penanggulangan tindak pidana terorisme khususnya dalam pasal 1 dengan memasukkan program deradikalisasi, deideologi ke dalam RUU tersebut, serta mengubah, menambah dan menyisipkan beberapa pasal ke dalam beberapa UU Penanggulangan Tindak Pidana Terorisme, yang dapat diterapkan melalui pendekatan politik yang dititikberatkan pada faktor penyebab terorisme.
\end{abstract}

Key word: kebijakan formulasi hukum pidana, tindak pidana teorisme, problematika sinergitas PolriTNI.

\section{ABSTRACT}

. This research is motivated by the existence of existing problems in the implementation of synergy between Polri, TNI and society in order to overcome the crime of terrorism, where the problem becomes a legal problematical when proposed of Terrorism Act. The problem of this research is how the problem of law in the implementation of synergy of Polri, TNI and the Society in the effort of overcoming terrorism crime, how the current criminal law policy applied in countering terrorism act and how policy of criminal law formulation applied in countering terrorism crime in future.

This research method is juridical empirical with data collection method of literature study, interview and observation. The conceptual framework in the study includes the concepts of criminal law policy, 
and the concept of criminal acts of terrorism. While this problem is analyzed by using the theory of state sovereignty and legal system theory.

The results of this study indicate that the problem of law in the implementation of synergy of the Police, TNI, Government and Society in the effort to overcome terrorism in Indonesia comes from: the difference of mission vision between Polri and TNI in the purpose of synergy for eradication of terrorism crime; different views on the Terrorism Bill between the Police and the Armed Forces; the emergence of a narrow mindset from some people who think that the issuance of Perkapolri no. 7 of 2008 on Basic Guidelines for Strategy and Improvement of Community Policing in Policing of Polri Duties, is considered as an effort to match the activities undertaken by Babinsa formed by the TNI. The current criminal justice policy in the context of combating terrorism in Indonesia is done, among others, through the application of the Law on Terrorism Crime, the Law on Eradication and Prevention of Terrorism Financing and Emergency Law on Firearms. The policy of formulation of criminal law in the framework of solving legal problems as an effort to overcome terrorism in Indonesia in the future, among others, is carried out by making changes in the draft law on combating terrorism especially in article 1 by incorporating deradicalization program, deideologi into The bill, as well as amending articles $6,14,15,25,28,31$ and 33, adds to Article 10 and inserts articles 12 A, 12 B into between Article 12 and Article 13; insert article 13 A between Articles 13 and 14; inserting Article 16 A between Articles 16 and 17; insert article 28 A between Articles 28 and 29; and insert article 32 one paragraph between paragraphs (1) and paragraph (2) of Article 32, which can be applied through a political approach that is focused on the causes of terrorism.

Key word: criminal law formulation policy, criminal theorism, problematic synergy of Polri-TNI.

\section{PENDAHULUAN}

Polri sebagai organisasi yang berada pada bidang pelayanan sekaligus juga organisasi yang memiliki kekuasaan dalam menjaga keamanan dan ketertiban masyarakat sosial yang telah memenuhi standar hukum, profesional dan proporsional memiliki kewajiban untuk menanggulangi hilangnya rasa aman ditengah-tengah masyarakat serta menanggulangi keprihatinan masyarakat Nasional dan Internasional yang diakibatkan oleh akibat aksi teror.

Farouk Muhammad dalam pelaksanaan sosialisasi pencegahan terorisme, menyatakan bahwa ${ }^{1}$ teror pada hakekatnya merupakan penyerangan psikologis (psywar atau perang urat saraf) dengan kekerasan yang dilakukan terselubung atau tidak langsung sehingga menimbulkan rasa takut atau khawatir dari obyek yang diserang. Dalam bentuk yang paling sederhana, teror dijumpai dalam kehidupan sosial, misalnya yang dilakukan oleh seseorang terhadap sebuah keluarga dalam bentuk fitnah, kabar bohong dan/atau hasutan/ancaman melalui telepon, yang paling komplek adalah pembajakan pesawat dan penyerangan/pemboman (bunuh diri) atau yang terakhir ini lebih dikenal dengan sebutan terorisme.

Melihat bahaya terorisme tersebut, maka Polri sebagai penegak hukum berdasarkan UndangUndang Republik Indonesia Nomor 2 Tahun 2002 tentang Kepolisian Negara Republik Indonesia, memiliki kewenangan melakukan penindakan terhadap aksi terorisme tersebut. Selain berdasarkan pada Undang-Undang Kepolisian Negara Republik Indonesia tersebut, tugas dan kewenanganan Polri dalam menindak pelaku terorisme ini juga didasarkan atas adanya pelanggaran Undang-Undang Republik Indonesia Nomor 12 tahun 1951 tentang Senjata Api, Amunisi dan bahan peledak, Undang-

\footnotetext{
${ }^{1}$ Muhammad, Farouk. 2013. Pencegahan Terorisme: Mendayagunakan Polmas dan Mengelola Kamneg Mulai Dari Desa. Seminar "Pelaksanaan Sosialisasi Pencegahan Terorisme Kepada Unsur Pemda, Binter TNI-AD dan Binmas Polri" yang diselenggarakan oleh BNPT pada 26 s.d 28 Nopember 2013, di Surabaya, Jawa Timur. HIm. 2.
} 
Undang Republik Indonesia nomor 3 tahun 2002 tentang Pertahanan Negara, Undang-Undang Republik Indonesia Nomor 15 tahun 2003 tentang Penanggulangan Tindak Pidana Terorisme dan Undang-Undang Republik Indonesia Nomor 9 tahun 2013 tentang pecegahan dan pemberantasan tindak pidana pendanaan terorisme.

Mengacu pada alasan di atas dan amanat Undang-Undang No. 2 Tahun 2002 Tentang Kepolisian Negara Republik Indonesia, Polri memiliki kewajiban untuk mewujudkan tujuan Nasional yaitu membentuk suatu pemerintahan Negara Indonesia yang melindungi segenap bangsa Indonesia dan seluruh tumpah darah Indonesia, dan untuk memajukkan kesejahteraan umum, mencerdaskan kehidupan bangsa, serta ikut melaksanakan ketertiban dunia yang berlandaskan kemerdekaan, perdamaian abadi dan keadilan sosial. Oleh karena itu Polri melakukan upaya pemberantasan terorisme, dengan lebih menekankan pada usaha menjaga keamanan nasional untuk menciptakan suatu perdamaian dalam bangsa, melakukan tindakan pencegahan dan penanggulangan terorisme di Indonesia. Namun melihat berbagai permasalahan yang dialami Polri pada saat melakukan penangkapan para teroris mengalami banyak kendala khususnya dari ketersediaan sarana dan prasarana, khususnya yang dipergunakan oleh Satuan Brimob yang sangat minim, seperti ketidaktersediaan sarana prasarana yang dikhususkan untuk melakukan pertempuran dihutan, helikopter, dan peralatan lain yang dibutuhkan untuk melakukan penyisiran maupun dropping logistik maupun personel yang ada di tengah hutan, tentu hal ini sangat memberikan dampak yang signifikan. Oleh karena itu, diperlukan bantuan TNI yang memiliki sarana dan prasarana pertempuran di hutan sebagaimana ketersediaan pesawat helikopter, untuk dipergunakan dalam operasi penangkapan terorisme yang dilakukan oleh Polri.

Melihat kondisi geografis wilayah Indonesia seperti kontur dan luasnya medan yang sulit, jumlah personil Brimob yang minim, hal ini dapat menjadi kendala utama dalam melakukan operasi penangkapan kelompok teroris belum berjalan sesuai dengan yang diharapkan. Selain itu adanya operasi-operasi lainnya diluar operasi khusus penangkapan teroris (Santoso) dengan sasaran yang sama namun tujuan yang berbeda dan tidak terkoordinasi dengan Satgas yang bertugas, hal ini menimbulkan kerancuan serta mengakibatkan pelaksanaan dan sasaran operasi menjadi bias bahkan rawan menimbulkan terjadinya gesekan/benturan antar personil di lapangan, yang tentunya hal ini menjadi permasalahan tersendiri yang harus dihadapi dilapangan, sehingga pelaksanaan operasi menjadi terhambat dalam melakukan penangkapan kelompok DPO tersebut. Permasalahan lainnya adalah adanya tindakan tidak disiplin personil operasi serta ketidaksolidan dari aparat keamanan baik yang tergabung dalam Satgas operasi seperti Satgas operasi Tinombala, maupun diluar Satgas Operasi Tinombala/Satgas Imbangan. Hal ini terjadi akibat dipengaruhi oleh dorongan kepentingan tertentu dan ego sektoral serta tingkat koordinasi maupun transparansi internal yang kurang maksimal, hal ini juga dapat menjadi celah gagalnya operasi penanganan terorisme tersebut.

Sinergitas antara Polri, TNI, Badan Nasional Penaggulangan Teroris (BNPT), Badan Intelijen Negara (BIN), Pemerintah yang tersebar di seluruh wilayah Indonesia dan dukungan seluruh komponen Masyarakat, sebagai sebuah jawaban yang tepat dalam rangka mewujudkan langkah kebijakan formulasi hukum pidana tersebut yang sangat dibutuhkan untuk menanggulangi bahaya terorisme sekaligus antisipasi dan cegah dini terhadap aksi-aksi terorisme. Sinergitas lembaga negara ini difungsikan untuk melakukan koordinasi antar unit anti teror maupun lintas Instansi agar operasi penanggulangan terorisme dapat dilakukan dengan cepat, tepat dan berhasil, sehingga permasalahan dari adanya ancaman kasus terorisme yang ada di Indonesia dapat ditangani seefektif mungkin. 
Kebijakan formulasi hukum pidana ini dapat berpedoman pada Undang-Undang nomor 3 tahun 2002 tentang Pertahanan Negara yang difungsikan untuk menutup potensi celah kegagalan kinerja yang disebabkan oleh minimnya kekuatan personil Satuan Brimob yang secara individu belum mampu menutup seluruh jalur distribusi logistik dari kelompok terorisme. Namun dengan dasar hukum tersebut terdapat problematika tersendiri pada sisi HAM. Di mana tujuan dari mewujudkan keamanan dapat saja dikesampingkan oleh Undang-Undang Pertahanan Negara tersebut, dan pelaku teroris dapat dipandang sebagai ancaman negara yang harus dimusnahkan, yang mana hal ini tidak sesuai dengan HAM dan bertentangan dengan Undang-Undang Nomor 2 Tahun 2002 Tentang Kepolisian Negara Republik Indonesia, yang lebih mendahulukan tindakan penyidikan sebelum melakukan tindakan apapun sebagaimana tindakan dalam pemberantasan para pelaku teroris.

Oleh karena itu diperlukan kajian hukum secara mendalam mengenai dasar-dasar pengambilan kebijakan formulasi hukum pidana tersebut yang diimplementasikan dalam pelaksanaan sinergitas Polri, TNI, Pemerintah dan Masyarakat dalam melakukan penanggulangan terorisme, agar upaya penegakan hukum yang dilakukan dalam pelaksanaan sinergitas tersebut tidak bertentangan dengan HAM. Sehingga pemberantasan terorisme dapat berjalan efektif sesuai dengan hukum yang berlaku, tercipta situasi Kamtibmas yang kondusif di Indonesia, dan hilangnya ancaman terbesar yang diduga dari aksi terorisme ini di berbagai wilayah Indonesia.

Berdasarkan latar belakang di atas, permasalahan dalam penelitian ini adalah bagaimana problematika hukum dalam pelaksanaan sinergitas Polri, TNI, Pemerintah dan Masyarakat dalam upaya penanggulangan tindak pidana terorisme di Indonesia? Bagaimana kebijakan hukum pidana dalam penanggulangan tindak pidana terorisme di Indonesia saat ini dan di masa yang akan datang?

\section{Metode Penelitian}

Pendekatan penelitian yang digunakan penulis dalam melakukan penelitian ini adalah yuridis empiris. Pendekatan yuridis dilihat sebagai norma atau das sollen, karena dalam membahas permasalahan penelitian ini menggunakan bahan-bahan hukum baik hukum yang tertulis maupun hukum yang tidak tertulis atau baik bahan hukum primer maupun bahan hukum sekunder. Pendekatan empiris ini dilakukan sebagai kenyataan sosial, kultural atau das sein, karena dalam penelitian ini digunakan data primer yang diperoleh dari lapangan. Jadi, pendekatan yuridis empiris dalam penelitian ini maksudnya dalam menganalisis permasalahan dilakukan dengan memadukan bahan-bahan hukum yang merupakan data sekunder dengan data primer yang diperoleh di lapangan. ${ }^{2}$ Pendekatan yuridis empiris ini dilaksanakan melalui kegiatan studi dokumen dan wawancara dan pengamatan sehingga menggambarkan hasil penelitian yang dilakukan dengan cara menganalisa fenomena dan fakta-fakta yang berkaitan dengan kebijakan formulasi hukum pidana dalam penanggulangan tindak pidana terorisme di Indonesia, yang selanjutnya dapat digunakan untuk menjawab permasalahan yang ada.

Spesifikasi penelitian dalam penelitian ini adalah deskriptif analitis. Penelitian ini dimaksudkan untuk memberikan gambaran secara rinci, sistematis dan menyeluruh mengenai segala hal yang berkaitan dengan problematika hukum dalam upaya penanggulangan tindak pidana terorisme di Indonesia dan kebijakan formulasi hukum pidana dalam rangka penyelesaian problematika hukum sebagai upaya penanggulangan tindak pidana terorisme di Indonesia di masa yang akan datang. Gambaran tersebut nantinya akan dianalisis dengan peraturan perundang-undangan yang berlaku dan berbagai teori yang digunakan dalam penelitian ini. Analisis diharapkan dapat mengungkapkan semua

\footnotetext{
${ }^{2}$ Soerjono Soekanto dan Sri Mamudji. 1985. Penelitian Hukum Normatif Suatu Tinjauan Singkat. Jakarta: Rajawali Pers. Hal 52.
} 
permasalahan hukum terkait dengan kebijakan formulasi hukum pidana dalam rangka penyelesaian problematika hukum sebagai upaya penanggulangan tindak pidana terorisme di Indonesia sehingga diperoleh penjelasan masalah sesuai dengan ketentuan hukum yang berlaku, sehingga mampu merumuskan kebijakan formulasi hukum pidana dalam rangka penyelesaian problematika hukum dalam pelaksanaan sinergitas Polri, TNI, Pemerintah dan Masyarakat dalam upaya penanggulangan tindak pidana terorisme di Indonesia di masa yang akan datang

\section{HASIL PENELITIAN DAN PEMBAHASAN}

\section{Problematika Hukum dalam Pelaksanaan Sinergitas Polri, TNI, Pemerintah dan Masyarakat dalam Upaya Penanggulangan Tindak Pidana Terorisme Di Indonesia}

Selama ini penanggulangan terorisme yang dilakukan secara bersinergi antara Polri, TNI dan Masyarakat hanya menitikberatkan pada faktor-faktor yang menyebabkan adanya timbulnya ancaman gangguan Kamtibmas. Ancaman ini muncul ketika terjadinya serangan teror, yang secara prinsip merupakan pelanggaran hukum, sehingga mekanisme yang dilakukan adalah melakukan penegakan hukum, yang dapat melibatkan seluruh elemen penegak hukum baik dimulai dari kepolisian, kejaksaan, lembaga peradilan hingga lembaga pemasyarakatan. Namun dalam pelaksanaan sinergitas ini ternyata tidak semulus yang dibayangkan, terdapat faktor korelatif yang muncul dalam pelaksanaan pemberantasan terorisme, di mana faktor korelatif tersebut salah satunya adalah adanya kesenjangan sosial dan konflik politik.

1. Kesenjangan sosial

Kesenjangan sosial ini muncul karena adanya perbedaan pada aspek-aspek berikut:

a) Kewenangan yang diberikan dari pemerintah kepada Polri dan TNI berbeda, yang mana hal ini ditunjukkan dari kondisi Polri sebagai komandan dalam operasi penangkapan kelompok teroris Santoso, sedangkan TNI sebagai kelompok perbantuan saja. Perbedaan kewenangan ini selanjutnya akan berdampak pada pertanggungjawabannya sehingga tidak menimbulkan abuse of power dari Polri dan TNI dalam pemberantasan terorisme.

b) Support logistik yang meliputi Uang Lauk Pauk, Uang Operasi Lapangan dan anggaran lainnya yang digunakan untuk pemberantasan terorisme, yang diberikan oleh Pemerintah kepada TNI dan Polri berbeda.

c) Persepsi antara Polri dan TNI yang berbeda terhadap tindak pidana terorisme, di mana Polri beranggapan bahwa terorisme adalah sebuah bentuk tindakan kejahatan yang penyelesaiannya perlu dilakukan penyelidikan terlebih dahulu sehigga HAM yang dimiliki oleh pelaku teror tidak dilanggar dalam metode penegakan hukum yang dilakukan oleh Polri tersebut. Sedangkan TNI memiliki doktrin kill or to be killed, serta adanya anggapan bahwa terorisme merupakan ancaman atas kedaulatan negara maka dari itu terorisme harus diberantas (dieksekusi), yang mana hal ini akan mengabaikan hak-hak azasi yang dimiliki oleh pelaku teror tersebut.

2. Konflik politik

Konflik politik yang terjadi pada saat dilakukannya sinergitas Polri TNI dalam penanggulangan terorisme selanjutnya adalah adanya kepentingan-kepentingan politik yang mana pada saat itu TNI memiliki kedekatan dengan Presiden Jokowi, yang sangat memungkinkan memberikan harapa besar bagi TNI untuk memiliki porsi yang lebih besar dalam penanggulangan terorisme, adanya keinginan Panglima TNI untuk membatasi peran Polri yang dinilai sudah out of track, yang mana tujuan dibalik itu semua adalah untuk meredam kekuata PDIP yang selama ini sudah menjalin kedekatan dengan Polri, maupun disinyalir untung mendapatkan dana anggaran 
yang diberikan kepada TNI lebih besar akibat kecemburuan sosial pemberian dana seperti Uang Lauk Pauk dan operasional dalam pemberantasan tindak pidana terorisme ini yang berbeda. Sehingga adaya kondisi politik inilah memicu pro kontra dalam RUU terorisme tersebut, yang pada intinya dapat diindikasikan dari adanya keinginan menguasai lahan basah sebagaimana anggaran pemerintah yang dikucurkan untuk penanggulangan aksi terorisme kepada aparat pemerintah yang bertugas menanggulangi kasus terorisme tersebut.

Faktor lainnya dapat diamati pada permasalahan yang timbul dari unsur TNI, yang mana unsur TNI memiliki visi misi yang berbeda dengan tujuan dilakukannya sinergitas ini. Perbedaan ini bisa ditujukkan dari adanya keinginan TNI yang lebih mendominasi dalam praktek perburuan kelompok Santoso, yang akhirnya terbukti dengan keputusan yang diambil oleh TNI untuk menembak mati Santoso, yang mana hal ini sudah menyalahi aturan dari rencanan pelaksanaan perburuan kelompok Santoso yang telah dibuat oleh Polri sebagai pemimpin dalam rangka penegakan hukum terhadap pelaku tindak pidana terorisme, serta sebagai upaya penanggulangan terorisme di Indonesia saat ini.

Dengan adanya fakta tersebut, diketahui bahwa sinergitas yang dilakukan antara Polri dan TNI memiliki problematika dalam memandang upaya penegakan hukum atas terjadinya tindak pidana terorisme, di mana pandangan Polri terfokus pada penegakan hukum yang harus diselesaikan secara hukum, sedangkan TNI sebagai alat pertahanan negara yang berpandangan bahwa terorisme merupakan ancaman kedaulatan negara yang harus segera diberantas dan dimusnahkan.

Berdasarkan adanya kondisi tersebut maka dapat diketahui bahwa sinergitas antara Polri dan TNI yang diupayakan sebagai metode penanggulangan terorisme yang tepat, belum mampu untuk menjangkau perkembangan mutakhir strategi dan modus tindak pidana terorisme yang ada saat ini dan di masa yang akan datang.

Berdasarkan adanya penjelasan tersebut maka diperlukan pengkajian mengenai landasan penanggulangan ancaman tindak pidana terorisme yang harus diterapkan dalam pelaksanaan sinergitas Polri, TNI dan masyarakat dalam penanggulangan terorisme agar sesuai dengan koridor tatanan, prinsip, dan norma hukum serta hak azasi manusia di negara Indonesia ini, agar kelak tidak menimbulkan problematika lagi dalam penegakan hukum di Indonesia.

Salah satu upaya yang dapat dilakukan dalam pelaksanaan sinergitas Polri, TNI dan masyarakat dalam penanggulangan terorisme agar seimbang, dapat dilakukan dengan cara pemberian jaminan keamanan dan perlindungan atas kebebasan, serta hak-hak individu, sehingga munculnya abuse of power yang mungkin saja muncul dalam praktik pemberantasan tindak pidana terorisme dapat dicegah dengan kebijakan hukum yang telah disepakati sebelumnya. Hal ini perlu dilakukan karena terorisme merupakan suatu bentuk tindak pidana sehingga penanganannya yang tepat harus menggunakan model pendekatan penegakan hukum pidana, yang mengikuti prinsip negara hukum, tatanan negara demokratik dan memberikan jaminan perlindungan kebebasan serta mewujudkan HAM.

Melihat adanya beberapa problematika tersebut dapat diketahui bahwa selama ini pendekatan criminal justice system model yang telah diterapkan sudah tepat dan benar, sehingga dengan adanya pendekatan tersebut sudah tepat dalam menempatkan Polri sebagai penegak hukum dan aktor terdepan dalam melakukan penegakan hukum atas terjadinya tindak pidana terorisme yang ada di Indonesia selama ini.

\section{Kebijakan Hukum Pidana dalam Penanggulangan Tindak Pidana Terorisme Di Indonesia Saat Ini}

Penanggulangan terorisme yang telah dilakukan oleh pemerintah Indonesia saat ini sesuai dengan Undang-Undang No. 15 Tahun 2003 Tentang Tindak Pidana Terorisme. Pelaksanaan undangundang tersebut selanjutnya diterapkan melalui upaya prevetif, preemtif dan represif sebagai berikut: 


\section{Upaya prevetif}

Upaya prevetif ini merupakan suatu bentuk pecegahan kejahata yang dilakukan sebelum kejahata itu terjadi. Upaya prevetif lebih diutamakan daripada upaya-upaya lainnya, karena tindakan pencegahan kejahatan dilakukan tanpa memberi peluang jatuhnya korban kejahatan tersebut.

Melihat efisiensi dari upaya prevetif ini, upaya pencegahan memberikan nilai lebih murah dan lebih mudah melakukan tindakan pencegahan tindak pidana terorisme. Hal ini dapat dilakukan dengan beberapa cara seperti memberikan taggugjawab sosial warga masyarakat melalui pemberian bantuan sosial, memberikan upaya peningkatan kesejahteraan masyarakat, melakukan kegiatan patroli yang ditujukan untuk pegamanan lingkungan masyarakat. Beberapa upaya tersebut harus dilakukan agar kondisi sosial tertentu yang mudah terjangkit oleh propaganda dapat segera dibenahi dan diperbaiki, sehingga dengan upaya tersebut propaganda yang digunakan oleh kelompok terorisme untuk memperoleh simpatisan gagal.

\section{Upaya preemtif}

Upaya preemtif adalah upaya pencegahan kejahatan dengan cara menanamkan nilai dan norma yang baik sehingga norma-norma tersebut mampu mengeliminasi diri seseorang. Artinya sugesti yang ada di diri seseorang yang mampu mempengaruhi perilaku jahat seseorang dapat dieliminasi dengan keyakinan atas norma-norma positif yang diajarkan tersebut. Dengan langkah tersebut maka pencegahan kejahatan akan lebih efektif.

3. Upaya represif

Upaya represif adalah penanganan tindak pidana setelah tindak pidana tersebut terjadi, yang dilakukan melalui penegakan hukum dan penjatuhan sanksi pidana kepada pelaku tindak pidana tersebut. Tindakan tersebut merupakan upaya pengamanan masyarakat dari suatu tindak pidana, agar masyarakat mampu dihidarka dari peristiwa keahata tersebut, sehigga kejahatan dapat dikendalikan melalui batas-batas toleransi masyarakat.

Tindakan-tindakan tersebut juga sesuai dengan pandangan hukum islam yang tersurat dalam Q.S. Al Baqarah ayat 190 dijelaskan makna jihad yang sebenarnya yaitu: Dan perangilah di jalan Allah orang-orang yang memerangi kamu. Dan janganlah kamu melampaui batas. Sesungguhnya Allah tidak menyukai orang-orang yang melampaui batas. ${ }^{3}$ Penjelasan ayat tersebut menunjukkan bahwa tindak pidana terorisme yang ada harus dilawan dengan cara memerangi tindakan terorisme tersebut. Yang mana berdasarkan hukum Islam, tindakan penanggulangan tindak pidana terorisme yang dilakukan melalui berbagai upaya di atas, sudah tepat untuk dilakukan. Karena tindak pidana terorisme bukanklah suatu jihad.

Sesuai dengan hukum Islam, penanggulangan tindak pidana terorisme yang dilakukan oleh Pemerintah juga dapat dilakukan dengan cara meluruskan pandangan terorisme sebagai suatu bentuk jihad. Berdasarka adanya kekeliruan tersebut maka upaya yang dapat dilakukan adalah memberika ajara agama yang memberikan identitas, kelompok, dan narasi mengenai terorisme yang sebenarnya, sehingga simpatisan terorisme yang didasari adanya kedekatan keagamaan dapat memiliki pandangan yang benar mengenai arti terorisme itu sendiri, sehingga masyarakat dapat megetahui, mampu mencirikan bahwa kegiatan yang dilakukan oleh suatu organisasi bersifat militan, dengan tingkat disiplin tinggi, dan ditanami indoktrinasi dan pelatihan, memiliki tujuan politik yang digerakkan melalui tindakan kriminal untuk pencapaian tujuannya, tidak mengindahkan norma yang berlaku dan adanya pemilihan sasaran yang menimbulkan efek psikologis tinggi sehingga berdampak pada ketakutan dan

\footnotetext{
${ }^{3}$ Q.S. Al Baqarah Ayat 190.
} 
kecemasan dengan disertai publikasi di setiap aksinya secara luas. Berdasarka adanya ciri tersebut, maka dapat dipastikan bahwa organisasi tersebut adalah organisasi terorisme.

Namun melihat dasar hukum pelaksaaan penanggulangan tidak pdiana terorisme yang didasarkan dalam Undang-Undang No. 15 Tahun 2003 Tentang Tindak Pidana Terorisme, diketahui bahwa dalam pelaksanaanya Undang-Undang tersebut memiliki kelemahan-kelemahan yang dicontohkan sebagai berikut:

1. Polri dalam melakukan pegungkapan terorisme harus memenuhi syarat formalitas kejahatan terorisme, yaitu 2 alat bukti sebagaimana yang tertuang dalam Pasal 26 UU Tindak Terorisme

2. Untuk melakukan langkah penyidikan selanjutnya Polri harus mendapat perintah dari Pengadilan negeri terlebih dahulu dengan lama waktu maksimal 3 hari.

Dengan adanya ketentuan tersebut tentu sangat menyita waktu bagi Polri ketika akan melakukan penyidikan, sehingga hal tersebut tidak relevan lagi mengingat ancaman terorisme yang dapat saja datang sewaktu-waktu, sedangkan dalam penyiapan aksi penyidikan, pergerakan intelijen semuanya berada di bawah layar yang tentunya membutuhka cukup waktu.

Kelemahan selanjutnya juga muncul dari adanya aturan yang menegaskan bahwa terduga teroris tidak boleh ditembak mati dan harus mendapatkan haknya untuk didampingi pegacara. Hal ini tentu tidak sesuai dengan spektrum terorisme yang sangat luas degan sifat dan karakter terorisme yang berbeda dengan tindak pidana lainnya, di mana tindak pidana terorisme merupakan kejahatan luar biasa yang dapat berupa jaringan lintas negara, dapat membunuh keberadapan manusia yang mana hal ini melanggar HAM umat mausia yang lebih bayak lagi, sehingga apabila seseorang telah terbukti sebagai pelaku teroris, maka hukuman yang selayaknya adalah pidana mati. Untuk mengatasi kelemahan-kelemahan dalam undang-undang tersebut yang dapat dilakukan adalah merevisi kelemahan yang ada dalam undang-udang tersebut, sehingga peraturan perundang-undangan yang dijadikan dasar dalam penanggulangan terorisme tidak melemahkan fungsi Polri.

\section{Kebijakan Formulasi Hukum Pidana dalam Rangka Penyelesaian Problematika Hukum Sebagai Upaya dalam Penanggulangan Tindak Pidana Terorisme Di Indonesia Di Masa yang Akan Datang}

Kebijakan formulasi hukum pidana dalam rangka penyelesaian problematika hukum sebagai upaya penanggulangan tindak pidana terorisme di Indonesia di masa yang akan datang dapat dilakukan dengan cara melaksanakan politik hukum dengan cara mengedepankan prinsip hukum yang mengarah pada penghormatan HAM. Hal ini perlu dilakukan mengingat Indonesia yang merupakan negara hukum memberikan pengakuan dan perlindungan terhadap HAM yang diwujudkan dalam kepastian hukum yang menjunjung nilai keadilan dan kemanfaatan hukum. ${ }^{4}$ Oleh karena itu dalam penanggulangan tindak pidana terorisme, dapat melakukan pembaharuan hukum khususnya yang termuat dalam Undang-undang tindak pidana terorisme.

Perubahan ini dapat dilihat terkait dengan adanya pertimbangan bahwa tindak pidana terorisme yang selama ini terjadi di Indonesia merupakan kejahatan luar biasa yang membahayakan ideologi negara, keamanan negara, kedaulatan negara, nilai-nilai kemanusiaan, dan berbagai aspek kehidupan bermasyarakat, berbangsa dan bernegara, serta bersifat lintas negara, terorganisasi, dan mempunyai jaringan luas sehingga pemberantasan tindak pidana terorisme perlu dilakukan secara luar biasa, terencana, terarah, terpadu, dan berkesinambungan, berdasarkan Pancasila dan UndangUndang Dasar Negara Republik Indonesia Tahun 1945.

Pembaharuan hukum yang termuat dalam Undang-undang tindak pidana terorisme selanjutnya juga dapat dipertimbangkan oleh adanya keterlibatan orang atau kelompok orang serta

\footnotetext{
${ }^{4}$ Sartjipto Rahardjo. 2006. Ilmu Hukum. Bandung: CV Citra Aditya Bakti. HIm. 34.
} 
keterlibatan warga negara Indonesia dalam organisasi tertentu di dalam dan/atau di luar negeri yang bermaksud melakukan permufakatan jahat yang mengarah pada tindak pidana terorisme, berpotensi mengancam keamanan bangsa dan negara, kesejahteraan masyarakat, serta perdamaian dunia. Oleh karena itu, untuk memberikan landasan hukum yang lebih kukuh guna menjamin pelindungan dan kepastian hukum dalam pemberantasan tindak pidana terorisme, serta untuk memenuhi kebutuhan dan perkembangan hukum dalam masyarakat, perlu dilakukan perubahan atas Undang-Undang Nomor 15 Tahun 2003 tentang Penetapan Peraturan Pemerintah Pengganti Undang-Undang Nomor 1 Tahun 2002 tentang Pemberantasan Tindak Pidana Terorisme Menjadi Undang-Undang.

Dengan adanya pertimbangan tersebut maka perlu dibentuk Undang-Undang tentang Perubahan atas Undang-Undang Nomor 15 Tahun 2003 tentang Penetapan Peraturan Pemerintah Pengganti Undang-Undang Nomor 1 Tahun 2002 tentang Pemberantasan Tindak Pidana Terorisme Menjadi Undang-Undang, sebagai berikut:

1. Ketentuan Pasal 1 diubah, sehingga berbunyi sebagai berikut:

a. Tindak Pidana Terorisme adalah segala perbuatan yang memenuhi unsur-unsur tindak pidana sesuai dengan ketentuan dalam Undang-Undang.

b. Setiap Orang adalah orang perseorangan atau Korporasi

c. Korporasi adalah kumpulan orang dan/atau kekayaan yang terorganisasi, baik merupakan badan hukum maupun bukan badan hukum

d. Kekerasan adalah setiap perbuatan penyalahgunaan kekuatan fisik dengan atau tanpa menggunakan sarana secara melawan hukum dan menimbulkan bahaya bagi badan, nyawa, dan kemerdekaan orang, termasuk menjadikan orang pingsan atau tidak berda

e. Ancaman kekerasan adalah setiap perbuatan secara melawan hukum berupa ucapan, tulisan, gambar, simbol, atau gerakan tubuh, baik dengan maupun tanpa menggunakan sarana dalam bentuk elektronik atau nonelektronik yang dapat menimbulkan rasa takut terhadap orang atau masyarakat secara luas atau mengekang kebebasan hakiki seseorang atau masyarakat

f. Pemerintah Republik Indonesia adalah pemerintah Republik Indonesia dan perwakilan Republik Indonesia di luar negeri

g. Perwakilan Negara Asing adalah perwakilan diplomatik dan konsuler asing beserta stafnya

h. Deradikalisasi adalah suatu proses yang dilakukan melalui metode sistematis dalam rangka reintegrasi sosial yang diterapkan terhadap orang atau kelompok orang yang terpapar paham radikal terorisme, dengan tujuan untuk menghilangkan atau mengurangi dan membalikkan proses radikalisasi yang telah terjadi

Berdasarkan adanya rumusan tersebut maka dalam penanggulangan tindak pidana terorisme, dapat mengedepankan pelaksanaan kegiatan deradikalisasi dengan menerapkan pendekatan hukum yang dapat dilaksanakan melalui program-program maupun kegiatan sebagai berikut:

1) Program Deradikalisasi

Deradekalisasi adalah langkah preventif yang kontraterorisme yang berupa strategi menetralkan paham-paham yang dianggap radikal dan membahayakan yang diterapkan tanpa menggunakan pendekatan kekerasan. Tujuannya adalah untuk mengembalikan pemahaman pelaku teror ke jalan yang benar dan ke jalan pemikiran yang lebih moderat, karena terorisme merupakan ancaman serius bagi dunia internasional maupun nasional. Oleh karea itu dibuatlah suatu formula pencegahan terorisme melalu deradikalisasi melalui penanggulangan dan pecegahan paham radikal.

2) Program Deideologi 
Deideologi adalah peniadaan atau penghapusan terhadap asas yag mejadi idetitas dan simbol ideologi organisasi politik dan organisasi masa, sebagaimana adanya tujuan pelemahan ideologi yag diajarkan oleh kaum terorisme sehingga negara tidak tergaggu degan ideologi terorisme tersebut. Yang menjadi target dari upaya deideologi adalah ideologi komunal (terorisme) surut dan melemah sehingga masa depan negara Indonesia berjalan dengan baik tanpa pertentangan dari adanya ideologi terorisme tersebut. ${ }^{5}$

2. Ketentuan Pasal 6 diubah sesuai dengan bunyi pasal 249 RUU KUHP

3. Penambahan pasal $10 \mathrm{~A}$ diantara pasal 10 dan 11

4. Di antara Pasal 12 dan Pasal 13 disisipkan 2 (dua) pasal, yakni Pasal 12A dan Pasal 12B

5. Di antara Pasal 13 dan Pasal 14 disisipkan 1 (satu) pasal, yakni Pasal $13 \mathrm{~A}$

6. Ketentuan Pasal 14 diubah

7. Ketentuan Pasal 15 diubah

8. Di antara Pasal 16 dan Pasal 17 disisipkan 1 (satu) pasal, yakni Pasal 16A

9. Ketentuan Pasal 25 diubah

10. Ketentuan Pasal 28 diubah

11. Di antara Pasal 28 dan Pasal 29 disisipkan 1 (satu) pasal, yakni Pasal

12. Ketentuan Pasal 31 diubah

13. Di antara ayat (1) dan ayat (2) Pasal 32 disisipkan 1 (satu) ayat, yakni ayat (1a) sehingga Pasal 32

14. Ketentuan Pasal 33 diubah

\section{PENUTUP}

\section{Simpulan}

Berdasarkan hasil pembahsan di atas, dapat disimpulkan bahwa :

1. Problematika hukum dalam pelaksanaan sinergitas Polri, TNI, Pemerintah dan Masyarakat dalam upaya penanggulangan tindak pidana terorisme di Indonesia berasal dari:

a. Perbedaan visi misi antara Polri dan TNI dalam tujuan dilakukannya sinergitas untuk pemberantasan tindak pidana terorisme, di mana TNI beranggapan bahwa terorisme merupakan ancaman kedaulatan negara yang harus segera diberantas dan dimusnahkan, sedangkan Polri berpandangan bahwa terorisme merupakan tindak pidana yang harus diselesaikan melalui criminal justice system model,

b. Perbedaan pandangan mengenai RUU Terorisme antara Polri dan TNI, di mana Polri ingin memperbaiki kelemahan yang ada dalam UU No. 15 Tahun 2003 Tentang Penanggulangan Tindak Pidana Terorisme, sedangkan TNI ingin membuat perubahan judul menjadi RUU Penanggulangan Aksi Terorisme, merubah definisi mengenai terorisme, serta merubah tugas dan wewenang TNI dalam penanggulangan terorisme.

c. Timbulnya pemikiran sempit dari sebagian masyarakat yang beranggapan bahwa dikeluarkannya Perkapolri No. 7 Tahun 2008 Tentang Pedoman Dasar Strategi dan Impelemntasi Pemolisian Masyarakat dalam Penyelenggaran Tugas Polri, dianggap sebagai upaya menandingi kegiatan yang dilakukan oleh Babinsa yang dibentuk oleh TNI.

2. Kebijakan hukum pidana yang diterapkan saat ini dalam rangka penanggulangan tindak pidana terorisme di Indonesia antara lain dilakukan dengan cara:

a. Pengimplemetasian Undang-Undang No. 15 Tahun 2003 Tentang Tindak Pidana Terorisme

\footnotetext{
${ }^{5}$ Taufiq Nugroho. 2003. Pasang Surut Hubuga Islam dan Negara Pancasila. Yogyakarta: Padma. HIm. 89.
} 

b. Pengimplemetasian Undang-Undang Nomor 9 Tahun 2013 Tentang Pemberantasan dan Pencegahan Tindak Pidana Pendanaan Terorisme
c. Pengimplemetasian Undang-Undang Darurat Nomor 12 Tahun 1951 Tentang Senjata Api

3. Kebijakan formulasi hukum pidana dalam rangka penyelesaian problematika hukum sebagai upaya dalam penanggulangan tindak pidana terorisme di Indonesia di masa yang akan datang antara lain:

a. Membuat perubahan dalam rancangan undang-undang penanggulangan tindak pidana terorisme khususnya dalam pasal 1 dengan memasukkan program deradikalisasi, deideologi ke dalam RUU tersebut, serta mengubah pasal 6, 14, 15, 25, 28, 31 dan 33.

b. Menambah pasal 10.

c. Menyisipkan pasal 12 A, 12 B ke diantara Pasal 12 dan Pasal 13; menyisipkan pasal 13 A di antara Pasal 13 dan Pasal 14; menyisipkan pasal 16 A di antara Pasal 16 dan Pasal 17; menyisipkan pasal 28 A di antara Pasal 28 dan Pasal 29; dan menyisipkan pasal 32 satu ayat diantara ayat (1) dan ayat (2) Pasal 32

d. Untuk melaksanakan kebijakan formulasi hukum pidana tersebut perlu dilakukan pendekatan politik yang dititikberatkan pada faktor penyebab terorisme, menghentikan aksi terorisme yang mengancam kehidupan bangsa, warga negara dan kepentingan nasional serta menciptakan lingkungan internasional yang tidak menyuburkan terorisme, memberdayakan masyarakat, membuat strategi penanggulangan terorisme berdasarkan pada level pola penanggulangan ancaman yang muncul dari faktor ekonomi, menanggulangi ancaman yang muncul dari potensi faktor keterasingan secara sosial dan budaya yang dapat menggiring terjadinya aksi terorisme, dan melakukan pemolisian masyarakat.

\section{SARAN} adalah:

Sehubungan dengan hasil temuan penelitian dan pembahasan, saran yang dapat disampaikan penulis

1. Menanggulangi tindak pidana terorisme dengan menerapkan aturan hukum yang sesuai dengan Undang-Undang Tindak Pidana Terorisme, Undang-Undang Pemberantasan dan Pencegahan Tindak Pidana Pendanaan Terorisme dan Undang-Undang Darurat Senjata Api, serta menerapkan kebijakan formulasi hukum pidana dalam rangka penanggulangan tindak pidana terorisme di masa yang akan datang antara lain pelaksanaan deradikalisasi, deidelogi, dan memberdayakan masyarakat, melalui pendekatan-pendekatan reedukasi, rehabilitasi, resosialisasi dan reintegrasi dalam melakukan penanggulangan terorisme dan melakukan deideologi kepada masyarakat agar tidak mudah terprovokasi oleh gerakan radikal yang mengarah ke aksi terorisme.

2. Menerapkan upaya peanggulangan tindak pidana terorisme dengan memperhatikan motif dilakukannya tindak pidana tersebut, sehingga dari pengetahuan adanya motif tersebut dapat diketahui permasalahan penyebabnya, sehingga dari pengetahuan tersebut dapat diberikan solusi penanggulangan yang tepat terhadap pelaku tindak pidana terorisme tersebut.

3. Bekerjasama dengan berbagai pihak utuk bersama-sama melakukan penanggulangan tindak pidana terorisme secara dini dengan berbagai cara dengan disertai MoU, agar tidak terjadi tumpang tindih kekuasaan untuk memperoleh kepentingan politik pada masing-masing pihak.

\section{DAFTAR PUSTAKA}

Al Qur'an Surat Al Baqarah

Al Qur'an Surat Al Maidah 
Adian Husaii. 2001. Jihad Osama Versus Amerika. Jakarta: Gema Isani Pers.

Arief, Barda Nawawi. 2014. Bunga Rampai Kebijakan Hukum Pidana: Perkembangan Penyusunan Konsep KUHP Baru. Edisi Kedua. Jakarta: Kencana Prenada Media Group.

Muhammad, Farouk. 2013. Pencegahan Terorisme: Mendayagunakan Polmas dan Mengelola Kamneg Mulai Dari Desa. Seminar "Pelaksanaan Sosialisasi Pencegahan Terorisme Kepada Unsur Pemda, Binter TNI-AD dan Binmas Polri" yang diselenggarakan oleh BNPT pada 26 s.d 28 Nopember 2013, di Surabaya, Jawa Timur.

Sartjipto Rahardjo. 2006. Ilmu Hukum. Bandung: CV Citra Aditya Bakti.

Soerjono Soekanto dan Sri Mamudji. 1985. Penelitian Hukum Normatif Suatu Tinjauan Singkat. Jakarta: Rajawali Pers.

Sudarto. 2007. Hukum dan Hukum Pidana. Bandung: Alumni.

Taufiq Nugroho. 2003. Pasang Surut Hubuga Islam dan Negara Pancasila. Yogyakarta: Padma. 